\title{
Successful repair of a penetrating wound of the thoracic aorta
}

\author{
T. R A M A N A THAN, K. SOMASUNDARAM, and \\ N . K . Y O N G \\ Department of Surgery, University of Malaya, Kuala Lumpar, Malaysia
}

\begin{abstract}
Ramanathan, T., Somasundaram, K., and Yong, N. K. (1975). Thorax, 30, 348-351. Successful repair of a penetrating wound of the thoracic aorta. Penetrating wounds of the aorta are not necessarily fatal. A successfully managed patient with a stab wound of the ascending aorta is reported, and some problems of management associated with such injuries are discussed.
\end{abstract}

Successful repair of penetrating injuries of the thoracic aorta is rare because of the massive blood loss and the inability to cross clamp the aorta safely and totally. From 1922 (Dshanelidze, 1926) to 1973,44 successfully treated cases have been reported. This paper reports another, reviews the literature, and discusses some problems of management associated with such injuries raised by previous reports.

\section{CASE REPORT}

A 23-year-old Malay man was stabbed in the right upper chest on 29 January 1974 . He was admitted to hospital within half an hour of the trauma.

Examination revealed the patient to be centrally cyanosed, restless, and sweaty. The pulse rate was $150 / \mathrm{min}$ and the blood pressure was $40 \mathrm{mmHg}$ systolic. Both carotids and radials were palpable. The heart was in sinus rhythm but the heart sounds were distant. Auscultation of the chest revealed markedly diminished air entry over the right chest which was dull to percussion. A $1.75 \mathrm{~cm}$ stab wound was found in the second right interspace $5.0 \mathrm{~cm}$ to the right of the sternal edge.

A provisional diagnosis of right haemothorax was made. A supine chest radiograph showed opacification of the right lung field and some widening of the superior mediastinum (Figure).

An immediate right anterolateral thoracotomy revealed one litre of blood in the pleural cavity, laceration of the superior mediastinal pleura, and the pericardial cavity tense with blood. On opening the pericardium the intrapericardial portion of the ascending aorta was seen to be lacerated on its anterolateral aspect. Haemostasis was achieved by a side clamp and the blood pressure was restored to a normal level. The laceration was sutured with a double row of over and over atraumatic 0000 silk sutures.

The postoperative course was uneventful and the patient was discharged two weeks after operfon tion perfectly well.

\section{DISCUSSION}

Our review of the literature revealed 44 patients successfully treated for penetrating wounds of the thoracic aorta. Detailed information is available in 24 of these cases (Table). In another 32 cases injury to the aorta was associated with a fistule between the aorta and cardiac chambers, aort and pulmonary arteries or aorta and systemie. veins.

Parmley, Mattingly, and Manion (1958), in 456 necropsies for penetrating wounds of the heart and aorta, found that $12 \%$ of patients survived more than one hour. The few patients who reached hospital alive were either transporte rapidly before exsanguination or survived becauso bleeding from small wounds had ceased.

Patients with penetrating injury of the aorto arriving in hospital alive are usually in severe shock. Their immediate management is by rapia transfusion with $O$ negative blood and the maine tenance of an adequate airway. Large amounts of $O$ negative and type specific blood must be avait able at short notice. Resuscitation must be promp and effective. The availability of large amount of blood and experience in resuscitating severe shocked patients partly accounted for the higit salvage rate in Vietnam casualties (Billy, Amate, and Rich, 1971). 


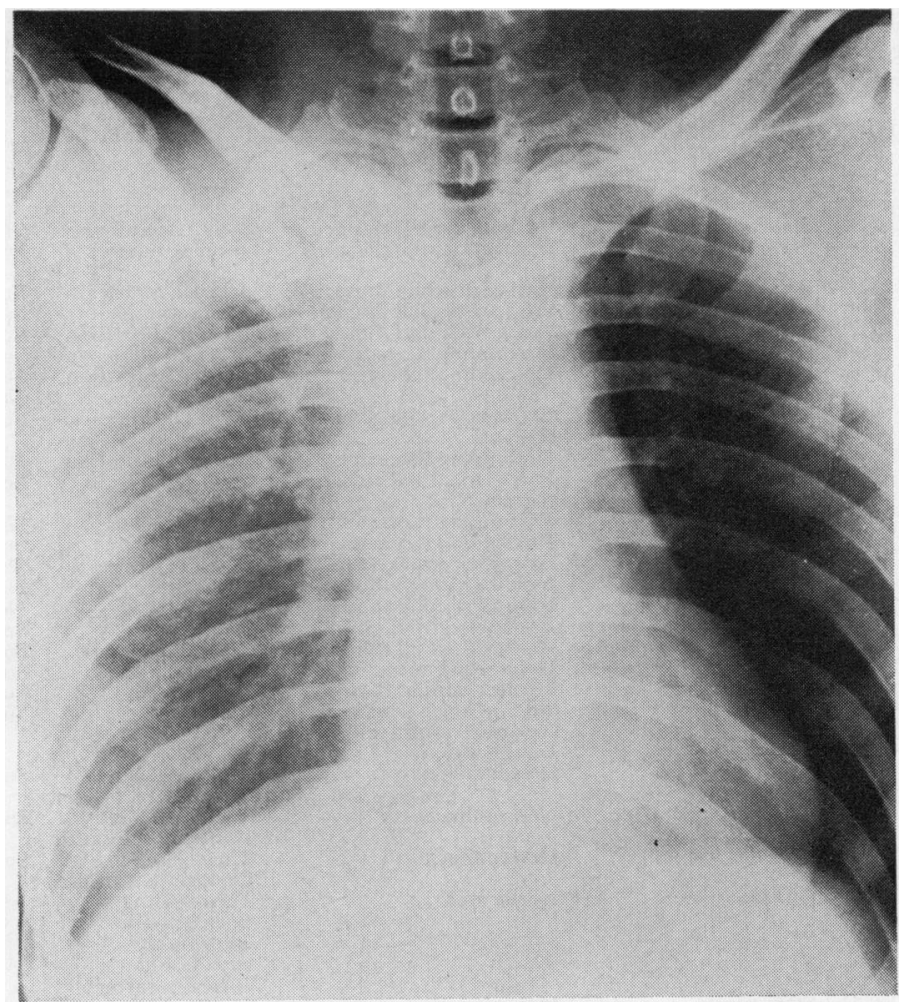

FIGURE Preoperative chest radiograph showing widening of mediastinum and opacification of the right hemithorax.

The diagnosis of penetrating wounds of the aorta is suspected by the trajectory of the missile or the direction of entry of the stabbing instrument or when bleeding is massive or continuous. The diagnosis is confirmed at thoracotomy.

Injury to the intrapericardial portion of the aorta isually results in tamponade, which may be relieved by pericardiocentesis. Associated haemothorax with or without pneumothorax necessitates the evacuation of blood and air from the pleural space. If sufficient blood is not available immediately, autotransfusion presents a possible solution to the problem of massive blood loss (Symbas and Sehdeva, 1970). Bleeding into the pericardium is sometimes compatible with survival (Diveley, Daniel, and Scott, 1961) as in our patient.

If bleeding is massive, thoracotomy is rapidly performed and haemostasis is achieved by digital compression. When bleeding is not massive or if the laceration is temporarily sealed by clot an aortogram can be performed. The patient must have large-bore polythene cannulae in the veins with facilities for rapid transfusion and transport to theatre for emergency thoracotomy should the patient collapse after the aortogram (Conn et al., 1971).

A stab wound of the side of the aorta can usually be repaired after partial tangential occlusion of the aorta. Through and through stab or bullet wounds frequently require proximal and distal cross-clamping of the aorta. Cross-clamping of the descending thoracic aorta is said to be safe if it lasts less than 20-30 minutes (Eiseman and Summers, 1955; Adams and van Geertruyden, 1956) but paraplegia has occurred after shorter periods of cross-clamping of the aorta (Symbas and Sehdeva, 1970). If the aorta has to be crossclamped, the use of a local bypass may afford protection to the spinal cord. The technique of cardiopulmonary bypass requires total body heparinization. Systemic heparinization may result in uncontrollable mediastinal haemorrhage after an otherwise successful operative repair and adequate neutralization of heparin (DeMeester, Cameron, and Gott, 1973). Alternatively, through and through laceration of the ascending aorta 
T A B L E

PENETRATING WOUNDS OF THE THORACIC AORTA SUCCESSFULLY REPAIRED $1922-73$

\begin{tabular}{|c|c|c|c|c|c|c|}
\hline Authors & Date & Cause of Injury & $\begin{array}{l}\text { Location of Aortic } \\
\text { Injury }\end{array}$ & Type of Injury & $\begin{array}{l}\text { Type of } \\
\text { Repair }\end{array}$ & $\begin{array}{c}\text { Interval } \\
\text { between Injury } \\
\text { and Definitive } \\
\text { Treatment }\end{array}$ \\
\hline $\begin{array}{l}\text { Dshanelidze } \\
\text { Blalock }\end{array}$ & $\begin{array}{l}1926 \\
1934\end{array}$ & $\begin{array}{l}\text { Stab wound } \\
\text { Stab wound }\end{array}$ & $\begin{array}{l}\text { Intrapericardial thoracic } \\
\text { Intrapericardial thoracic }\end{array}$ & $\begin{array}{l}1 \mathrm{~cm} \text { Laceration } \\
\text { Ice pick injury }\end{array}$ & $\begin{array}{l}\text { Suture } \\
\text { Suture }\end{array}$ & $\begin{array}{l}\text { Not stated } \\
\text { Soon after }\end{array}$ \\
\hline $\begin{array}{l}\text { Elkin } \\
\text { Elkin } \\
\text { Beattie and Greer } \\
\text { Keeley } \\
\text { Kleinert }\end{array}$ & $\begin{array}{l}1941 \\
1944 \\
1952 \\
1958 \\
1958\end{array}$ & $\begin{array}{l}\text { Stab wound } \\
\text { Stab wound } \\
\text { Stab wound } \\
\text { Gunshot wound } \\
\text { Gunshot wound }\end{array}$ & $\begin{array}{l}\text { Intrapericardial thoracic } \\
\text { Intrapericardial thoracic } \\
\text { Intrapericardial thoracic } \\
\text { Descending thoracic } \\
\text { Descending thoracic }\end{array}$ & $\begin{array}{l}\text { Ice pick injury } \\
\text { Knife wound } \\
14 \mathrm{~mm} \text { Laceration } \\
\text { Not known } \\
1.5 \mathrm{~cm} \text { Laceration }\end{array}$ & $\begin{array}{l}\text { Suture } \\
\text { Suture } \\
\text { Suture } \\
\text { Suture } \\
\text { Suture and }\end{array}$ & $\begin{array}{l}\text { admission } \\
\overline{48} \text { hours } \\
\text { Not stated } \\
\text { Not stated }\end{array}$ \\
\hline Perkins and Elchos & 1958 & Stab wound & $\begin{array}{l}\text { Extrapericardial ascending } \\
\text { thoracic }\end{array}$ & $2 \mathrm{~cm}$ Laceration & $\begin{array}{l}\text { patch } \\
\text { Suture }\end{array}$ & 2 hours \\
\hline $\begin{array}{l}\text { Baret et al. } \\
\text { McCann }\end{array}$ & $\begin{array}{l}1958 \\
1958\end{array}$ & $\begin{array}{l}\text { Stab wound } \\
\text { Ice pick }\end{array}$ & $\begin{array}{l}\text { Descending thoracic } \\
\text { Extrapericardial ascending } \\
\text { thoracic }\end{array}$ & $\begin{array}{l}1.5 \mathrm{~cm} \text { Laceration } \\
1 \mathrm{~cm} \text { Laceration }\end{array}$ & $\begin{array}{l}\text { Suture } \\
\text { Suture }\end{array}$ & $\begin{array}{l}29 \text { hours } \\
\text { Immediately }\end{array}$ \\
\hline $\begin{array}{l}\text { Linberg } \\
\text { Beall } \\
\text { Diveley et al. } \\
\text { Beall et al. } \\
\text { Beall et al. } \\
\text { Stelzner and Horatz } \\
\text { Overbeck and Gruenagel } \\
\text { Symbas and Sehdeva } \\
\text { Symbas and Sehdeva } \\
\text { Conn et al. }\end{array}$ & $\begin{array}{l}1959 \\
1960 \\
1961 \\
1962 \\
1962 \\
1963 \\
1968 \\
1970 \\
1970 \\
1971\end{array}$ & $\begin{array}{l}\text { Gunshot wound } \\
\text { Gunshot wound } \\
\text { Missile-wire } \\
\text { Stab wound } \\
\text { Stab wound } \\
\text { Gunshot wound } \\
\text { Missile-metal splinter } \\
\text { Stab wound } \\
\text { Stab wound } \\
\text { Gunshot wound }\end{array}$ & $\begin{array}{l}\text { Descending thoracic } \\
\text { Descending thoracic } \\
\text { Extrapericardial thoracic } \\
\text { Intrapericardial thoracic } \\
\text { Intrapericardial thoracic } \\
\text { Extrapericardial ascending } \\
\text { Intrapericardial thoracic } \\
\text { Descending aorta } \\
\text { Intrapericardial thoracic } \\
\text { Arch of aorta-between L. } \\
\text { common carotid and } \\
\text { L. subclavian }\end{array}$ & $\begin{array}{l}4 \cdot 5 \mathrm{~mm} \text { diam. } \\
\text { Laceration } \\
3-4 \mathrm{~mm} \text { Ho!e } \\
\text { Not stated } \\
\text { Not stated } \\
\text { Small bullet } \\
3 \text { mm Laceration } \\
\text { Laceration } \\
\text { Laceration } \\
\text { Perforation }\end{array}$ & $\begin{array}{l}\text { Suture } \\
\text { Suture } \\
\text { Suture } \\
\text { Not stated } \\
\text { Not stated } \\
\text { Suture } \\
\text { Suture } \\
\text { Suture } \\
\text { Suture } \\
\text { Suture }\end{array}$ & $\begin{array}{l}2 \text { hours } \\
\text { Immediate } \\
36-48 \text { hours } \\
\text { Immediate } \\
\text { Immediate } \\
30 \text { minutes } \\
3 \text { hours } \\
\text { Not stated } \\
\text { Not stated } \\
5-6 \text { hours }\end{array}$ \\
\hline & 1970 & Gunshot wound & Descending aorta & $\begin{array}{l}\text { Through and } \\
\text { through perforation }\end{array}$ & Suture & Not stated \\
\hline Fromm et al. & 1970 & Gunshot wound & Descending aorta & $\begin{array}{l}\text { Through and } \\
\text { through perforation }\end{array}$ & Suture & $\begin{array}{l}\text { Minutes after } \\
\text { admission }\end{array}$ \\
\hline Fromm et al. & 1970 & Gunshot wound & Descending aorta & $\begin{array}{l}\text { Through and } \\
\text { through perforation }\end{array}$ & Suture & \\
\hline DeMeester et al. & 1973 & Gunshot wound & Aortic arch & $\begin{array}{l}\text { Through and } \\
\text { through and } \\
\text { avulsion of } \\
\text { origin of } L \text {. } \\
\text { common carotid }\end{array}$ & Suture & Immediately \\
\hline Present study & 1974 & Stab wound & Intrapericardial aorta & $1 \mathrm{~cm}$ Laceration & Suture & 30 minutes \\
\hline
\end{tabular}

can be repaired under hypothermia and inflow occlusion. The ascending aorta is opened and the laceration of the posterior wall sutured. The aortotomy is then controlled by a side clamp and the cavae are released (Diveley et al., 1961). DeMeester et al. (1973) used a heparinized polyvinyl shunt between the ascending aorta and the left femoral artery in the operative treatment of a through and through gunshot wound of the arch of the aorta with avulsion of the origin of the left common carotid artery. Kirsh et al. (1970) used a non-heparinized shunt in patients with acute traumatic rupture of the aorta. They state that total heparinization is not needed and clotting does not occur in the shunt once flow has started in it. The use of heparinized shunts is probably safer in very sick patients with low blood pressure and an increased risk of cardiac arrest during surgery.

\section{REFERENCES}

Adams, H. D. and van Geertruyden, H. H. (1956). Neurological complications of aortic surgery. Annals of Surgery, 144, 574.

Baret, A. C., Delong, R. P., Tukanowicx, S. A., and
Blakemore, W. S. (1958). Transfixion of the aor accompanied by a Brown-Séquard syndrome. $\Phi$ case report. Journal of Thoracic and Cardiova cular Surgery, 35, 359.

Beall, A. C. Jr (1960). Penetrating wounds of th aorta. American Journal of Surgery, 99, 770.

- - Roof, W. R., and DeBakey, M. E. (1962) Successful surgical management of through-and through stab wound of the aortic arch. Annals 9 Surgery, 156, 823.

Beattie, E. J. and Greer, D. (1952). Laceration of the aorta. A case report of successful repair fort eight hours after injury. Journal of Thoracic aros Cardiovascular Surgery, 23, 293.

Billy, L. J., Amato, J. J., and Rich, N. M. (1971 Aortic injuries in Vietnam. Surgery, 70, 385. $\omega$

Blalock, A. (1934). Successful suture of wound of the ascending aorta. Journal of the American Medice Association, 103, 1617.

Conn, J. H., Hardy, J. D., Chavez, C. M., and Faiß尺 W. R. (1971). Challenging arterial injuries Journal of Trauma, 11, 167.

DeMeester, T. R., Cameron, J. L., and Gott, V. $\frac{\overrightarrow{\mathrm{P}}}{\mathrm{P}}$ (1973). Repair of a through-and-through gunsh wound of the aortic arch using a heparinisel shunt. Annals of Thoracic Surgery, 16, 193.

Diveley, W. L., Daniel, R. A., and Scott, H. W. (1961). Surgical management of penetrating injuries 
the ascending aorta and aortic arch. Journal of Thoracic and Cardiovascular Surgery, 41, 23.

Dshanelidze, I. I. (1926). Manuskript, Petrograd 1922. Cited by Lilienthal, $\mathrm{H}$. in Thoracic Surgery. The Surgical Treatment of Thoracic Diseases, p. 489. Saunders, Philadelphia.

Eiseman, B. and Summers, W. B. (1955). Factors affecting spinal cord ischemia during aortic occlusion. Surgery, 38, 1063.

Elkin, D. C. (1941). Diagnosis and treatment of cardiac trauma. Annals of Surgery, 114, 169.

(1944). Wounds of the heart. Annals of Surgery, $120,817$.

Fromm, S. H., Carrasquilla, C., and Lucas, C. (1970). The management of gunshot wounds of the aorta. Archives of Surgery, 101, 388.

Keeley, J. L. (1958). Discussion of Kleinert, H. E. Homograft patch repair of bullet wounds of the aorta. Archives of Surgery, 76, 811.

Kirsh, M. M., Kahn, D. R., Crane, J. D., Anastasia, L. F., Lui, A. H., Moores, W. Y., Vathayanon, S., Bookstein, J. J., and Sloan, H. (1970). Repair of acute traumatic rupture of the aorta without extracorporeal circulation. Annals of Thoracic Surgery, 10, 227.

Kleinert, H. E. (1958). Homograft patch repair of bullet wounds of the aorta. Archives of Surgery, 76, 811.
Linberg, E. J. (1959). Bullet wound of thoracic aorta with survival. Maryland State Medical Journal, 8, 285.

McCann, W. J. (1958). Successful repair of a stab wound of the ascending aorta. New York State Journal of Medicine, 58, 3177.

Overbeck, W. and Gruenagel, H. H. (1968). Iron splinter injury of the intrapericardial aorta. Thoraxchirurgie, 16, 274.

Parmley, L. F., Mattingly, T. W., and Manion, W. C. (1958). Penetrating wounds of the heart and aorta. Circulation, 17, 953.

Perkins, R. and Elchos, T. (1958). Stab wounds of the aortic arch. Annals of Surgery, 147, 83.

Stelzner, F. and Horatz, K. (1963). Successful correction of gunshot wounds of extrapericardial ascending aorta. Thoraxchirurgie, 10, 632.

Symbas, P. N. and Sehdeva, J. S. (1970). Penetrating wounds of the thoracic aorta. Annals of Surgery, 171, 441 .

Requests for reprints to: T. Ramanathan, F. R. C. S., Lecturer in Surgery, Department of Surgery, University of Malaya, Kuala Lumpur, Malaysia. 